\section{POIMEN : Jurnal Pastoral Konseling \\ ISSN (Print) : 2723-5645 \\ ISSN (Online) : 2723-5637}

http://ejournal-iakn-manado.ac.id/index.php/poimen

Vol.1, No.2, pp. 1 - 84, Desember 2020
IAKN MANADO

FAKULTAS TEOLOGI

PRODI PASTORAL KONSELING

\begin{tabular}{|l|l|}
\hline Diterima & 15 November 2020 \\
\hline Disetujui & 28 Desember 2020 \\
\hline
\end{tabular}

\title{
MAKNA KONSELING DALAM KITAB SUCI
}

\author{
Steven Tubagus \\ Sekolah Tinggi Teologi Injili Setia Siau, Email: tubagussteven@gmail.com
}

\begin{abstract}
Abstrak
Krisis Konseling dirasakan oleh semua orang, kurang kepercayaan kepada konselor. Berdasarkan itu perlu sumbangsih bagi konseling pastoral dalam membimbing berdasarkan kitab suci. Makna Konseling dalam Kitab Suci. Tujuan tulisan ini adalah untuk mendeksripsikan makna Konseling dalam kitab suci secara Teologis. Metode yang digunakan adalah kualitatif, dengan memakai studi literatur yaitu Alkitab dan buku refrensi. Hasil penelitian yaitu konseling pastoral bahwa Allah mengasihi semua orang terlepas dari kehidupan kita yang penuh dengan dosa sekalipun. Makna Konseling dalam Kitab Suci yaitu pertama, menjadi ciptaan baru di dalam Kristus. Kedua, Mempunyai Pikiran yang Baru untuk Dunia Baru. Ketiga, Mempunyai Hati yang Baru. Keempat, Menjadi murid Yesus.
\end{abstract}

Kata kunci: Makna, Konseling, Kitab Suci

\begin{abstract}
The counseling crisis is felt by everyone, lacking trust in the counselor. Based on that, it is necessary to contribute to pastoral counseling in guiding according to the scriptures. The Meaning of Counseling in the Scriptures. The purpose of this paper is to describe the meaning of counseling in the scriptures theologically. The method used is qualitative, using literature studies, namely the Bible and reference books. The results of the study are pastoral counseling that God loves all people regardless of our lives filled with sin though. The meaning of Counseling in the Scriptures is first, to become a new creation in Christ. Second, Have a New Mind for the New World. Third, Have a New Heart. Fourth, Become a disciple of Jesus
\end{abstract}

Keywords: Meaning, Counseling, Scripture 


\section{A. PENDAHULUAN}

Krisis Konseling dirasakan oleh semua orang, kurang kepercayaan kepada konselor. Apakah identitas anda yang sebenarnya? Sejak Adam memilih untuk tidak taat kepada Tuhan diTaman Eden, dia dan semua keturunannya telah diidentifikasikan dengan dosa. Pernyataan tidak mau bergantung pada Tuhan menerangkan sifat memberontak yang masing-masing telah kita warisi. Karena kita dilahirkan kedalam keluarga Adam, kita semua memiliki kecenderungan alamiah untuk menjalankan kehidupan yang terpusat pada diri sendiri. ${ }^{1}$

Krisis identitas adalah sebuah periode transisi yang sulit menjadi dewasa. Yang tampak sangat bertentangan dengan diri sendiri yang sebenarnya sehingga menyebabkan rasa sakit yaitu kecemasan dan keinginan untuk berubah tetapi sulit untuk keluar dari itu karena ada rasa takut dan minder. Di sini tugasnya orang beriman untuk bisa menolong supaya mereka bisa keluar dari takut karena merek adalah milik Tuhan dan harus di tolong. ${ }^{2}$

Mempunyai alasan dan kesempatan untuk menjalani kehidupan yang memberi teladan. Orang tua menciptakan suasana adem dan positif dirumah sehingga mereka yakin suatu saat ia akan menjadi teladan bagi semua orang. Kemenangan yang luar biasa dialami oleh siapapun. bisa keluar dari kegagalan moral itu adalah anugerah. Kehidupan manusia terutama dalam hidup mempunyai cerita dan bakat yang harus dikembangkan. Untuk mengembangkan perlu mentor sehingga ada bimbingan dan tujuan yang terarah. ${ }^{3}$

Seorang Guru selalu diperlukan oleh setiap generasi disetiap zaman. Guru yang diinginkan adalah yang hidup sesuai dengan standar keyakinan moralnya; yang dinyatakan lulus dan patut menjadi teladan adalah yang memiliki intergritas. Ada banyak orang yang menemukan harapan dan dorongan dalam diri Guru. Guru adalah pahlawan yang tanpa tanda jasa, yang dapat bertahan ditengah tekanan hidup disetiap generasi termasuk generasi millenial, yang tidak termakan rayuan walaupun mereka mendapat tekanan untuk menarik kembali keputusan mereka, dan mengubah keyakinan mereka. ${ }^{4}$ Konseling adalah penyuluhan kepada konseli untuk mengatasi suatu masalah karena manusia membutuhkan suatu teman untuk berbagi masalah sehingga masalah itu bisa terpecahkan lewat 2 pemikiran, lewat teman konseli akan curhat dan meras nyaman.

\footnotetext{
1 June Hunt, Konseling Alkitabiah 2: Kebenaran Alkitab Menjawab Masalah Anda (Yogyakarta: ANDI Offset, 2015). 73

${ }^{2}$ Hadiwijono Harun, Iman Kristen (Jakarta: BPK Gunung Mulia, 2003). 262

${ }^{3}$ Howard Clinebell, Tipe-Tipe Dasar Pendampingan Dan Konseling Pastoral (Yogyakarta: Kanisius, 2002). 83

${ }^{4}$ Yohan Brek, Ibadah Generasi Milenial: Pendekatan Teologi Pastoral Dalam Generasi Milenial (Depok: Raja Grafindo Persada, 2019). 249
} 


\section{B. DESKRIPSI TEORETIK}

\section{Menjadi Ciptaan Baru di dalam Kristus}

Setiap orang mempunyai emosi memerlukan penanganan yang berbeda-beda, bergantung kepaa kepribaian masing-masing. Ada yang sangat terbuka tetapi ada pula yang sulit untuk mengutarakan perasaannya, dan sangat tertutup. Dalam hal ini kebudayaan dal latar belakang keluarga sering kali sangat menentukan, kadang-kadang ada keluarga dimana keterbukaan sangat dianjurkan, tetapi ada keluarga yang jarang sekali mengutarakan perasaan, bahkan tidak pernah dibicarakan tetapi kita tahu bahwa setiap konsele bisa diliputi oleh perasaan kecewa, frustasi, gelisah, rasa bersalah, ataupun kuatir. Masalah identitas yaitu jati diri, dimana seorang anak ingin mencari jati diri terkatang seorang anak salah jalan karena belum mengetahui jati dirinya sehingga menimbulkan pikiran negatif dan moral mereka tidak bagus artinya seorang anak ingin tahu, keinginan tahu dan merasakan membuat dirinya salah jalan dan tidak bisa keluar dari masalah. Disinilah diperlukan seorang mentor yang akan membimbing anak kejalan yang benar. Jalan yang benar mempunyai moral yang layak di teladani. Jadi masa dewasa adalah mencari jati diri sehingga bisa menjadi baik dan bisa menjadi jahat. ${ }^{5}$

Tuhan Yesus tidak selalu memakai cara yang lama, kadang-kadang Ia berkhotbah kadang-kadang Ia mendengar, memerintahkan, berdebat, dan mengajar bagaimana kita dapat menjadi anak-anak yang baik. Ia berbicara di Bait Allah, di atas bukit, dirumahrumah dan tidak pernah menghadapi suatu persoalan dengan cara yang sama; karena Tuhan mengerti perbedaan dalam kepribadian, kebutuhan, dan tingkat pengetahuan tiap orang. Jadi Ia menggunakan cara-cara yang unik untuk setiap permasalahan. Tugas seorang konselor adalah memberikan apa yang dibutuhkan konsele saat itu. Tuhan Yesus mengasihi kita semua, sehingga di waktu membutuhkan Tuhan, Tuhan selalu hadir dan menjawab apa yang kita butuhkan. ${ }^{6}$

Konseling adalah suatu interpersonal relationship, suatu dialog yang terjadi antara dua individu yang bisa melibatkan seluruh aspek kehidupan yang mereka miliki. Gal. 6:15 Kebenaran harus diungkapkan karena kalau tidak diungkapkan akan menjadi masalah, masalah dalam kehidupan manusia adalah masalah yang harus dipecahkan bersama-sama ketika masalah itu dipecahkan maka sukacita memenuhi hidup kita, di dlaam Kristus tidak yang tersembunyi semua akan terungkap. Konseling adalah percakapan terapeutik antara konselor dengan konselingnya. Perlunya kejujuran manusia sehingga terjadi komunikasi antara konselor dan konseling sehingga bisa menjadi ciptaan baru di dalam Kristus. ${ }^{7}$

Pertemuan dengan Yesus adalah membuat seseorang akan jujur, dan ada perubahan, semua orang ketika ada percakapan dengan Yesus hidupnya akan berubah, yang dulunya berbuat dosa sekarang tidak. Seorang Perempuan Samaria ketika bertemu Yesus, pesan Yesus adalah jangan berbuat dosa lagi. Pesan itu didengar dan lakukan sehingga tidak

\footnotetext{
${ }^{5}$ Elizabeth B. Hurlock, Psikologi Perkembangan Suatu Pendekatan Sepanjang Rentang Kehidupan (Jakarta: Erlangga, 2009). 246

${ }^{6}$ Gary R Collins, Konseling Kristen Yang Efektif: Pengantar Pelayanan (Malang: Literatur SAAT, 2012). 42

${ }^{7}$ Susabda B. Yakub, Konseling Pastoral (Jakarta: BPK Gunung Mulia, 2014). 5-6
} 
berbuat dosa lagi dengan demikian dosanya telah dikuburkan., supaya nama Tuhan dimuliakan dalam hidupnya. Rm 6:4. Murid harus menambil sikap dan pelayanan Yesus di dalam kehidupan sehari-hari, tugas pastoral bukan hanya bukan hanya pendeta tetapi setiap orang yang menjadi murid-Nya. ${ }^{8}$

Menjalin hubungan dengan baik adalah menjadi teman dan pendengar yang setia. Semua orang ingin mengungkapkan perasaannya baik itu perasaan marah maupun perasaan sedih sehingga ketika perasaan itu keluar, orang tersebut merasa nyaman dan hatinya senang. Tapi di dalam Kitab Suci berkta jika engkau marah berkata-katalah di tempat tidurmu. Marah adalah membuat diri seseorang akan menjadi masalah, ketika pasti seseorang akan berkata kasar dan melukai hati orang lain dan hati yang terluka ini harus diobati kalau tidak akan menjadi kepahitan menimbulkan dendam. Ini tugas konseling untuk menghilangkan dendam dalam hatinya. Elihu mengkonfrontasikan Ayub dengan kebenaran-kebenaran Allah (Ayb. 33:12).. strategi terbik untuk menolong adalah dengan menjadi pendengar yang baik sehingga di waktu konselor bicara, konseling pasti mendengarkan. Konseling merasa dihargai dan pastinya konseling mau hidup baru di dalam Tuhan dengan mengoreksi kehidupannya ${ }^{9}$

Tuhan Yesus mmenyuruh semua orang menjauhi masalah, ketika masalah datang cepat untuk berdamai sehingga hati kita menjadi baru setiap hari. Konseling yaitu suatu usaha dalam sistematika, yang di dalamnya studi tentang sifat manusia ditempuh dalam kesadaran interaksinya dengan sains tingkah laku dan manusia. ${ }^{10}$ Berdoa adalah percakapan dengan Tuhan, baiknya ketika ada masalah datang kepada Tuhan Yesus dan keluar isi hati dalam arti bercakap-cakap sehingga ada hikmat untuk menyelesaikan suatu masalahsehingga tubuh, jiwa dan roh tetap terpelihara (1Tesalonika 5:23).

Konselor yang tidak pernah berbicara tenatang Kristus dalam percakapan konselingnya, tetapi sering kali juga banyak konselor yang membicarakan hal-hal rohani dengan gegabah atau terlalu cepat. Seorang konselor harus sensitif terhadap pimpinan Roh Kudus, dan percaya, bahwa Ia akan membimbing dan menunjukkan saatnya yang tepat untuk berbicara hal rohani. Orang-orang yang datang pada kita dan minta bimbingan biasanya datang dengan persoalan yang kompleks, baik jasmani, gejala-gejla kejiwaan maupun kebutuhan rohani. Karena itu, jangan kita hanya menekankan hal yang spiritual dan melupakan gejala yang lain, yang juga harus ditaati; atau pun sebaliknya kita memperhatikan gejala-gejala jasmani dan kejiwaan saja serta meremehkan kebutuhan rohani. Hukum utama dan amanat yang agung, keduanya mengajarkan kepada kita untuk melihat atau memfokuskan diri pada seluruh keberadaan manusia dan kebutuhannya. ${ }^{11}$ Ketika hidup di pimpin oleh Roh Kudus seseorang akan mengubur masa lalunya yaitu kehidupan manusia lama dan hidup menjadi manusia baru dan benar-benar hidup dalam pertobatan.

\section{Mempunyai Pikiran yang Baru untuk Dunia Baru}

\footnotetext{
${ }^{8}$ Aart van Beek, Pendampingan Pastoral (Jakarta: BPK Gunung Mulia, 2007). 10

${ }^{9}$ Toni Lake, Pergumulan Di Kala Duka (Jakarta: BPK Gunung Mulia, 1992). 5

${ }^{10}$ Mesach Krisetya, Bela Rasa Yang Dibagirasakan (Jakarta: Duta Ministri, 2015). 22

${ }^{11}$ Martin Van Beek, Konseling Pastoral (Semarang: Satya Wacana, 1992). 3
} 
Tetapi perli diingat, bahwa terlalu sering mengalami stres yaitu pikirannya sedang terganggu, terutama yang berat, akibatnya juga tidak baik. Efeknya dapat terlihat nyata, dalam hubungan dengan:

1). Fisik: stres sering kali menimbulkan kelemahan tubuh dan berbagai penyakit. Serangan jantung, sakit maag, sakit kepala dan banyak penyakit yang lain, sering kali timbul karena stres. Karena gelisah, kesepian, kesulitan, rasa bersalah atau putus asa seseorang sering tidak dapat sembuh dari penyakit dideritanya. Hal ini disebabkan karena pikiran lama yang menanggung beban dan kemampuan melawan penyakit yang sangat berkurang. Pikiran yang berlebihan akan menimbukan stres dan mempengaruhi kesehatan.

2). Pikiran adalah gagasan dan proses mental (1Kor. 2:16). Pikiran yang mengusai manusia jika terlalu banyak berlikir maka manusia akan sakit. manusia dapat berubah dalam sedetik ikiran yang lama dalam arti pikiran buruk yaitu berpikir negatif kepada teman bisa menjadi pikiran yang baru yaitu berpikir positif. Berpikir positif membuat seseorang akan hidupnya lebih indah. Biasakan hidup selalu bersyukur, dengan bersyukur kita menerima hidup dengan sukacita dengan tidak mengeluh, pikiran menjadi baru ketika kita bersyukur.

3). Mental: pada waktu stres sering kali kita diam dan tidak mengerjakan apa, bertele-tele, mudah tersinggung dan tidak dapat kerja lama dengan orang lain. Problem dalam pernikahan sering kali muncul karena suami/istri mengalami stres dalam pekerjaan, sehingga tidak peka dengan kebutuhan pasangannya dirumah. Dalam kehidupan digereja pun seringkali kita menyaksikan betaa ketegangan dan pertengkaran yang terjadi antara pendeta dengan pendeta, pendeta denga jemaat timbul sebagai akibat dari komunikasi orang-orang yang mengalami stres.

4). Rohani: memang bagi rasul Paulus, stres yang ia alami justru mendekatkan dia kepada Kristus. Namun tidak sedikit yang mengalami, bahwa stres justru menghambat pertumbuhan rohaninya. Dalam keadaan stres, pusat perhatian kita sering kali pada masalah kita sendiri, dan kita lupa datang kepada Tuhan dalam doa dan membaca serta merenungkan firman Tuhan. Sehingga penghiburan yang dari Tuhan tidak kita rasakan dan perasaan tertekan menjadi semakin kuat. Kita perlu Tuhan untuk bisa sembuh dari stres, ketika kita sembuh hidup menjadi pikiran baru dan hidup baru di dalam Kristus. ${ }^{12}$

Untuk pikiran yang baru muncul pada masa depan, maka akan diperlukan bagi orang untuk mengambil kekuasaan kembali ke dalam mekanisme mereka sendiri persepsi, untuk memberdayakan diri mereka sendiri dengan legitimasi pemotongan mengenai mode tua dan usang berpikir. Perubahan ini, kemudian, mengharuskan kita untuk memutuskan dengan hati-hati apa yang kita pikirkan, bagaimana kita berpikir, dan keyakinan yang kita pilih untuk mengadopsi. Ini juga menyangkut pendapat kita, perjanjian, dan dukungan, yang kita sebelumnya telah terlalu siap untuk memberikan. Keyakinan kita, persepsi, dan keadaan pikiran sangat penting untuk bagaimana kita memahami dunia di sekitar kita. Dengan demikian, memberikan hak kita kekuasaan untuk memilih bagaimana kita ingin melihat dunia berfungsi untuk memberdayakan orang lain atas kita. Hal ini, pada dasarnya, adalah inti dari kontrol sosial. Kesadaran adalah kunci utama untuk berpikiran baru untuk

${ }^{12}$ Collins, Konseling Kristen Yang Efektif: Pengantar Pelayanan. 90 
dunia baru. Jadi ini injil memberikan kebenaran yang bersifat objektif. ${ }^{13}$ Ketika menerima injil bukan lagi berpikir positi tapi kehidupan manusia tidak ada lagi berpikiran negatif.

Bagaimana menolong orang-orang yang kesepian? Menolong mereka melihat pentingnya membangun hubungan Allah dalam Tuhan Yesus Kristus. Pengakuan dosa dan kesediaan untuk menerima Tuhan Yesus. Menerima Tuhan Yesus dengan sendirinya telah meninggalkan kesepian dan menerima pikiran yang baru dan dunia yang baru. Elia, seperti yang disaksikan oleh kitab suci mengalami kekecewaan, kejengkelan, kekuatiran, kecemasan dan kesepian. Ini adalah gejala-gejala yang biasanya menyertai setiap orang mengalami kesepian, oleh pertolongan Tuhan dapat diatasi oleh Elia.

Firman Tuhan itu menuntun orang dijalan yang benar, yang tidak tahu menjadi tahu, sehingga ketika ada masalah hendaklan membaca kitab suci sehingga ada ketenangan supaya jangan terlalu cepat mengambil suatu keputusan dan mengakibatkan suatu kesalahan yang besar. Baiknya setiap masalah harus selalu bertanya kepada Tuhan Yesus sehingga tidak salah mengambil suatu keputusan, bisa juga bertanya kepada konselor kristen, pastinya seorang konselor kristen akan mengarahkan dijalan yang benar sesuai dengan firman Tuhan. Firman sebagai "Cermin" agar kita bisa berubah, karena firman adalah Allah. ${ }^{14}$ Dari dalam penjara, Paulus dapat mengembangkan pikiran-pikran untuk membalas dendam, kebencian dan kasihan terhadap diri sendiri. Namun heran sekali ia justru menulis dalah satu surat yang menjadi master piece (karya utama) mengenai prinsipprinsip kesehatan mental yang pernah ditulis oleh manusia. "Saudara-saudara semua yang baik dan benar (Flp. 4:8).

\section{Mempunyai Hati yang Baru}

Selama berbulan-bulan Tuhan Yesus mengajarkan kepada kedua belas murid-Nya dan memperlihatkan kepada mereka kuasa untuk menyembukan penyakit, mengusir setan, dan lain-lain. Mereka melihat dengan mata kepala sendiri kuasa dari khotbah-nya di bukit, bahkan kebijaksanaan dan kasih-Nya yang mendalam. Setelah itu Tuhan Yesus mengutus mereka untuk melayani. Mat. 10:8 Kamu telah menerima dengan Cuma-Cuma karena itu berikanlah dengan Cuma-Cuma (Rm. 6:4). ${ }^{15}$ Sebagai konselor kristen, kita seharusnya belajar bagaimana Tuhan Yesus mempersiapkan murid-murid-Nya untuk keluar melayani. Ia memberikan kuasa dan penghiburan, bahwa mereka tidak sendiri oleh karena kuasa dari Tuhan akan menyertai mereka.

Tetaplah mempunyai hubungan baik dengan banyak orang. Ada kecenderungan dari banyak orang, bila mengalami kesulitan selalu mau menyendiri dan berusaha mengatasi masalah sendiri. Padahal, tidak seharusnya demkian, karena persoalan akan dapat

\footnotetext{
13 YUSUF L M, “Yesus Sejarah Dan Kristus Iman," Veritas Lux Mea (Jurnal Teologi dan Pendidikan Kristen) 2, no. 1 (May 7, 2020): 1-19, accessed July 22, 2020, http://jurnal.sttkn.ac.id/index.php/Veritas/article/view/62.

${ }^{14}$ Yusuf L. M., "INTERPRETASI KATA LOGOS DAN THEOS DALAM YOHANES 1:1," BONAFIDE: Jurnal Teologi dan Pendidikan Kristen 1, no. 1 (June 15, 2020): 23-43, accessed July 22, 2020, http://jurnal.sttissiau.ac.id/index.php/jbs/article/view/1.

15 Totok S. Wirsyaputra, Mengapa Berduka Kreatif Mengelola Perasaan Berduka (Yogyakarta: Kanisius, 2003). 24
} 
diselesaikan bila ada kemauan untuk membagikan dan mengutarakan pada orang lain. Kedukaan adalah penderitaan batin yang sangat dalam kebodohan sendiri. ${ }^{16}$

Dengan kita belajar untuk menanggung beban sesama maka segala persoalan hidup dapat kita hadapi dengan lebh mudah. Tuhan Yesus mempunyai teman-teman dekat dimana Ia dapat pergumulan-pergumulan hati-Nya dengan lebih mudah. Para hamba Tuhan seringkali menemukan kesulitan untuk mengutarakannya problem kepada orang yang dapat bicara. Minta kepada Tuhan yang akan menyediakan orang yang sesuai kriteria kita dalam arti dapat menguatkan dan menghibur. Kitab Suci menegaskan bahwa proses pertumbuhan bukanlah proses terjadinya dengan sendirinya, melainkan campur tangan Tuhan dalam Mazmur 139:13-14. ${ }^{17}$

Masih mengutip Hurlock, secara umum pola perkembangan emosi anak meliputi 9 aspek, yaitu rasa takut, malu, khawatir, cemas, marah, cemburu, duka cita, rasa ingin tahu, dan gembira. Pertama, rasa takut yaitu perasaan yang khas pada anak, hampir setia fras usia, seorang anak mengalami ketakutan dengan kadar yang berbeda-beda. Rangsangan yang umumnya menimbulkan rasa takut pada bayi adalah suara yang terlalu keras, binatang yang menyeramkan,, kamar gelap, tempat yang tinggi, dan kesendirian. Pada usia 2 sampai 6 tahun, anak akan mengalami puncak ketakutan yang khas. Sebab pada usia ini anak lebih mengenal bahaya dari pada masa bayi. Hanya saja, karena kurangnya pengalaman, anak tidak bisa membedakan antara bahaya yang mengancam dan yang tidak mengancam.

Kedua, raa marah yaitu sikap penolakan yang kuat terhadap apa yang tidak ia sukai. Dalam pandangan anak, ekspresi kemarahan merupakan jalan yang paling cepat untuk menarik perhatian orang lain. Umumnya, situai yang menimbulkan kemarahan meliputi berbagai macam batasan: rintangan yang menghalangi gerak anak, rintangan terhadap keinginan, rencana dan niat yang ingin dilakukan dan sejumlah kejengkelan lain yang terus menumpuk, sementara reaksi yang ditimbulkan sesuai kadar kemarahannya. Semakin tinggi kemarahan anak, semakin keras pula ia menunjukkan sifat marahnya, mulai dari diam, berkata keras, gerak verbal, hingga tindakan-tindakan anarkis lainnya.

Ketiga, rasa ingin tahu. Setiap anak mempunyai naluri ingin tahu yang sangat tinggi. Mereka menaruh minat terhadap segala sesuatu di lingkungan mereka, termasuk diri mereka sendiri. Semakin luas lingkungan anak-anak, semakin luas pula mereka mempunyau rasa ingin tahu. Sebab setiap ada hal yang baru, mereka selalu ingin tahu. Reaksi ingin tahu ini biasanya diekspresikan dengan membuka mulut, menengadakan kepala, dan mengerutkan dahi. ${ }^{18}$

Kenapa belajar tentang perkembangan emosi anak karena ini sangat mempengaruhi dalam konseling yaitu ketika kita konseling seseorang maka harus mengetahui kepribadian seseorang supaya tidak ada selisih paham, misalnya orang ini kita melihat sifatnya ceria maka kita tanpa kita bertanya orang itu sudah bertanya duluan, kalau seseorang yang akan dikonseling mempunyai kepribadiannya pemalu maka konselor harus mengajak bicara

\footnotetext{
${ }^{16}$ Totok S. Wiryasaputra, Grief Psychotheraphy (Yogyakarta: Pustaka Referensi, 2019). 23

${ }^{17}$ Rupp Anne Neufeld, Tumbuh Kembang Bersama Anak (Jakarta: BPK Gunung Mulia, 2009). 184

${ }^{18}$ Suyadi, Psikologi Belajar Pendidikan Anak Usia Dini (Yogyakarta: Pt. Bintang Pustaka Abadi., 2010). 110
} 
duluan maka seseorang akan merasa nyaman dan mau bercerita. Dari pemikiran yang dipikirkan itu tidak masuk akal menjadi masuk akan karena mengenal kepribadian seseorang dengan cara seperti menjadi mudah untuk masuk dalam kehidupannya. Semua orang yang dulunya cenderung berpikir irasional sekarang menjadi rasional, penjelasan Kitab Suci mampu memberikan penjelasan-penjealsan yang lebih ilmiah. ${ }^{19}$

Konseling akan menjadi sempurna ketika mengetahui kepribadiannya, kalau seseorang mempunyai pendiam, yang sebagai konselor harus ajak bicara sehingga terjadi komunikasi. Mengetahu sifat atau kepribadian seseorang itu memudahkan kita dalam menjalankan tugas untuk menyelesaikan suatu masalah. Konseling harus mampu melihat manusia dalam keutuhannya dalam hidupnya yaitu individu secara fisik, mental dan spritual. ${ }^{20}$ Banyak orang terlalu sibuk, baik dengan pekerjaan maupun aktivitas yang lain dan tidak mempunyai waktu untuk membaca dan menambah pengetahuan. Walaupun Daniel sibuk, ia tetap tidak ketinggalan dan mungkin ia memaksakan dirinya untuk terus mengembangkan pengetahuan yang telah didapatnya. Tentunya ia waspada, ia dapat kehilangan kepekaannya, tumpul dan tidak berpikir secara baik saa masalah muncul dan membutuhkan perhatian besar.

Kesehatan yang baik adalah bagaimana bisa keluarkan unek-unek dalam diri kita dalam arti berbagi masalah sehingga masalah bisa terpecahkan dan mendapat jalan keluar. Ketika seseorang menceritakan masalah pribadi maka seseorang itu akan merasa puas karena diperhatikan dan peduli pada dirinya, situlah kesempatan untuk seorang konselor untuk masuk dalam percakapan sehingga konseli merasa bahwa ada sahabat yang baik, itu juga mempengaruhi kesehatannya karena ketika dia merasa senang kitab suci berkata bahwa hati yang gembira adalah obat yang manjur. Kesehatan yang matang lerletak pada ketergantungan pada Tuhan Yesus. ${ }^{21}$ Jagalah kesehatan, kita telah belajar, bahwa Daniel menjaga dan memperhatikan kesehatan tubuhnya. Tuhan Yesus sendiri mengambil waktu untuk istirahat, dan orang-orang kristen sepanjang abad mengerti akan pentingnya makanan dan olah raga yang baik. Jika tubuh kita lemah, tentu kemampuan untuk mengatasi problema juga akan berkurang.

\section{Menjadi Murid Yesus}

Menjadi murid berarti mengikuti Dia. Frasa "Ikutlah Aku" (deute opisō mou, ayat 19a) secara hurufiah berarti "datanglah sesudah Aku" (YLT "come ye after me"). Seorang murid akan mengikuti gurunya ke mana saja guru itu pergi. Mereka tinggal bersama-sama, memeluk ajarannya, dan meniru gaya hidupnya. Pendeknya, menjadi murid berarti selalu bersama supaya menjadi sama. Frasa "Ikutlah Aku" bukanlah sebuah undangan. Bukan salah satu opsi di antara sekian banyak pilihan. Ini adalah perintah. Siapa saja yang serius dengan Yesus wajib mengikuti Dia. Murid mengalami kesulitan yang berkaitan dengan

\footnotetext{
${ }^{19}$ Gerben Heitink, Teologi Praktis Pastoral Dalam Era Modernitas-Postmodernitas (Jakarta: Kanisius, 1999). 55

${ }^{20}$ Aart Martin van Beek, Stretegi Pelayanan Terpadu-Suatu Pedoman Pastoral (Jakarta: Pelkesi, 1992). 10

${ }^{21}$ Malcom Brownlee, Gotong Royong Dan Berdikari, Dalam Eka Darmaputera (Ed), Konteks

Berteologi Di Indonesia (Jakarta: BPK Gunung Mulia, 2004). 249
} 
konseling pastoral atau pembimbingan pada jemaat yang bermasalah serta bergumul dan yang membutuhkan pendekatan teologis. ${ }^{22}$

Menjadi murid juga berarti menjalankan misi-Nya. Yesus tidak berhenti pada "Ikutlah Aku". Dia langsung menambahkan "kamu akan Kujadikan penjala manusia" (ayat 19b). Ini adalah tujuan dari pemuridan. Bukan sekadar belajar, belajar dan belajar. Kita belajar supaya nanti bisa menjadi pengajar dan memuridkan orang lain. Matius 28:19-20a

Sebagian orang merasa kurang percaya diri dengan tugas ini. Beragam dalih diberikan untuk menghindari tugas ini (misalnya tidak fasih berbicara, belum layak, dsb). Semua alasan ini menyiratkan asumsi yang keliru. Yang paling berperan dalam proses persiapan ini adalah Yesus Kristus. Dalam teks Yunani, ayat 19b berbunyi: "Aku akan menjadikan kalian penjala manusia" (bdk. semua versi Inggris). Dia yang aktif menjadikan. Tugas kita hanya mengikuti prosesnya saja. Kurang percaya diri untuk menjalankan misi-Nya berarti kurang memercayai bahwa Dia mampu untuk memampukan kita. Yesus Kristus bukan hanya mengambil inisiatif, tetapi Dia juga selalu aktif di dalam seluruh prosesnya. Pelayanan yang diterima nampaknya tidak jauh berbeda dengan pelayanan konseling nonpastoral. ${ }^{23}$

Yohanes 1:35-51 kita akan mengetahui bahwa peristiwa di Matius 4:18-22 bukanlah perjumpaan mereka yang pertama dengan Yesus. Sebelumnya mereka sudah pernah bertemu dan menyaksikan mujizat-mujizat Yesus. Pada perjumpaan pertama tersebut mereka belum mendapat panggilan untuk mengikuti Yesus. Mereka hanya ingin tahu dan menghabiskan waktu beberapa saat dengan Yesus (Yoh. 1:38-39). Jadi, kisah di Matius 4:18-22 merupakan tindakan lanjut dari pertemuan-pertemuan sebelumnya. Tidak heran, murid-murid bisa langsung memberikan respons yang sangat cepat. Seorang pendamping harus memiliki kualitas tertentu, untuk membantu dan memperlancar relasi konseling; dia memiliki pengetahuan dasar teori dan praktek konseling, serta memiliki berbagai keterampilan konseling seperti keterampilan wawancara, interview serta melibatkan orang yang dilayani dalam memecahkan masalah. ${ }^{24}$

Peranan hamba Tuhan sebagai konselor besar sekali setelah konsele kembali ke rumah sakit karena sumber tekanan hidup baik dari keluarga maupun dari masyrakat. Perasaan malu pernah drawat di rumah sakit jiwa, sering kali menambha tekanan. Hamba-hamba Tuhan dan seluruh jemaat harus dilatih untu benar-benar bisa menerima atau menyambut mereka yang pernah di rawat di rumah sakit jiwa untuk dapat menyesuaikan diri. Menolong berarti memperlakukan mereka secara normal. Karakteristik pendamping yang diharapkan jemaat adalah pendampingan yang tulus hati, memiliki keahlian untuk mendengar sehingga jemaat dapat mengutarakan permasalahan atau atau pergumulan yang lebih leluasa. Sekilas respons ini tidak terlalu sukar untuk dilakukan. Semua terjadi dengan begitu cepat (ayat 20 "segera"; ayat 22 "segera"). Bagaimanapun, jikat kita melihat dari perspektif kuno waktu

\footnotetext{
${ }^{22}$ Kristiana Tjandrarini, Bimbingan Konseling Keluarga (Salatiga: Widya Sari Press, 2004). 6

${ }^{23}$ E. P. Gintings, Gembala \& Konseling Pastoral (Yogyakarta: ANDI Offset, 2002). 2

${ }^{24}$ Sutarno, Di Dalam Dunia Tetapi Tidak Dari Dunia (Jakarta: BPK Gunung Mulia, 2004). XVii
} 
itu, respons tersebut sangat radikal. Mengikuti Yesus berarti meninggalkan hal-hal yang lain yang mungkin berharga. ${ }^{25}$

Pertama, meninggalkan pekerjaan (ayat 20). Pola pemuridan pada waktu itu tidak memungkinkan bagi seseorang untuk menjalankan pekerjaan sehari-hari seperti biasanya. Pemuridan dan pekerjaan sukar untuk dijalankan secara bersamaan dengan maksimal. Seorang murid akan mengikuti gurunya ke mana saja dia pergi. Terikat dengan suatu pekerjaan jelas akan menjadi kendala yang besar. Pilihan perlu diambil. Dalam proses pendampingan, jemaat akan merasa nyaman sewaktu melakukan pendampingan dengan pendampingan untuk memiliki kerendahan hati, sebab suasana cukup kondusif, tidak ada keraguan untuk menceritakan semua pergumulan atau permasalahan yang dihadapi. ${ }^{26}$

Pada permulaan konseling, paling tidak ada tiga tujuan yang harus dicapai, yaitu bertemu dengan konsele, membangun hubungan baik, dan menjelaskan persoalan yang dihadapi konsele. Bertemu dengan konsele, tentu saja konseling tidak bisa dimulai bila kita sendiri tidak pernah bertemu dengan orang yang membutuhkan bimbingan tersebut. Untuk memulai pelayanan konseling kita harus menyatakan kesediaan kita untuk menolong. Membangun hubungan dengan baik, sejak permulaan memang perlu membangun hubungan baik dengan konsele sehingga ia merasa rileks dan dapat mempercayai anda sebagai komselor. Menjealskan persoalan yang dihadapi, pada mmulanya, memang kelihataannya mudah, namun tidak selamanya demikian. Banyak orang yang merasa sulit untuk mengutarakan persoalannya. Walaupun mereka alam keadaan kesulitan, mereka sendiri tidak mengerti bagaimana harus mengungkapkan apa persoalan yang sedang dihadapinya. Karena itu sebagai konselor, tugas kita adalah untuk mendengar dan memperhatikan apa yang ia katakan, mendorong dia untuk menjelaskan lebih lanjut, memberi komentar atau pertanyaan, sehingga kita bisa mempunyai gambaran yang lebih jelas mengenai kepribadiannya, dan jangan terburu-buru untuk mnyelesaikan suatu maslaah. Walaupun demikian, prinsip yang diajarkan tetap sama: pemuridan lebih penting dari pada pekerjaan. Jangan sampai karena pekerjaan, kita melupakan proses menjadi murid Tuhan. Sebaliknya, pekerjaan tersebut harus menjadi salah satu proses pemuridan. Maksudnya, kita belajar menerapkan sifat dan ajaran Kristus dalam pekerjaan kita. Tuhan rohani $^{27}$

\section{METODOLOGI}

Penelitian ini memakai Metode yang digunakan adalah kualitatif, dengan memakai studi literatur yaitu Alkitab dan buku refrensi. Dengan pendekatan Studi literatur Alkitab, penelitian ini melihat makna yang terkandung didalam konseling pastoral. ${ }^{28}$ Teknik

\footnotetext{
${ }^{25}$ Totok S. Wiryasaputra, Ready to Care (Yogyakarta: Galang Press, 2006). 99-120

${ }^{26}$ Carry R. Collins, Pengantar Pelayanan Konseling Kriten Yang Efektif (Malang: Seminari Alkitab Asia Tenggara, 2002). 10

${ }^{27}$ Wayne E. Oates, Pastoral Caunseling (Philadelphina: The Westminster Press, 1974). 12

${ }^{28}$ Nawawi, Metode Penelitian Kualitatif (Jakarta: Gramedia, 2003). 13
} 
pengumpulan data menggunakan cara observasi, wawancara dan analisis sehingga penelitian ini bisa di pertanggung jawabkan ${ }^{29}$

Analisis adalah penguraian atau kupasan suatu pokok atas berbagai bagiannya dan penelaan bagian taks dalam kitab suci serta hubungan antar teks yang satu dengan teks yang lain yang berada dalam kitab suci untuk memperoleh pengertian yang tepat dan pemahaman arti keseluruhan ${ }^{30}$

Hal mempelajari Kitab Suci secara sistematik dan teliti untuk menemukan arti asli yang dimaksudkan. Pada dasarnya hal ini adalah suatu tugas yang berkenaan dengan sejarah. Suatu usaha untuk mendengar firman Tuhan sebagaimana penerima mula-mula mendengarkannya, untuk menemukan apa yang dimaksudkan oleh perkataan Kitab Suci ${ }^{31}$

\section{HASIL DAN PEMBAHASAN}

Hasil yang pertama, menjadi ciptaan baru adalah menjadi milik Kristus, kitab suci berkata siapa yang ada didalam Kristus ia adalah ciptaan baru. Menjalin hubungan dengan Tuhan dengan baik yaitu dengan menjauhi masalah sehingga tidak kena masalah. Hidup bisa menjadi berkat bagi mereka yang membutuhkan konseling sehingga kita bisa membawa mereka dijalan yang benar dengan cara memberitakan firman Tuhan.

Hasil yang Kedua, mempunyai pikiran yang baru untuk dunia yang baru adalah pikiran yang berpusat kepada Kristus sehingga semua pelayanan konseling bisa diselesaikan dengan baik dalam arti pikiran kita tidak jenuh dan merasa kesepian. Orang pikiran yang berpusat kepada Tuhan, selalu ceria dan bersukacita karena di dalam Kristus tidak pergumulan yang tidak bisa diselesaikan, semua masalah bisa diselesaikan asal kita mempunyai pikiran yang baru untuk dunia yang baru.

Hasil yang ketiga, mempunyai hati yang baru adalah mendapat hati yang baru sebab tertulis dalam kitab suci aalah kamu akan Kuberikan hati yang baru. Hati yang baru adalah hati yang taat kepada Tuhan, ketika kita taat, tidak akan sakit, tidak akan ada masalah karena selalu taat kepada Tuhan. Tidak akan sakit karena selalu menjaga kesehatan dan selalu membaca firman Tuhan sehingga menjadi sehat secara jasmani dan rohani setiap hari.

Hasil yang keempat, menjadi murid Yesus, menjadi murid adalah menjadi orang percaya didalam Kristus. Menjadi murid Yesus adalah di akui oleh bapa bahwa kita adalah anak dan pastinya akan menerima janji yaitu keselamatan. Belajar mengikuti teladan bapa yaitu hidup benar dan tidak berbuat dosa, suatu kebanggan menjadi murid dialam Kristus, upahnya pasti sorga.

\section{E. PENUTUP}

\footnotetext{
${ }^{29}$ Imam Gunawan, Metode Penelitian Kualitatif, Teori Dan Praktik (Jakarta: Bumi Aksara, 2013). 148-151

${ }^{30}$ Budiono, Kamus Ilmiah Populer Internasional: Materi Politik, Ekonomi, Hukum, Sosial, Budaya, Agama. (Surabaya: Alumni, 2005).

${ }^{31}$ Gordon D. Fee \& Douglas Stuart, Hermeneutik: Bagaimana Menafsirkan Firman Tuhan Dengan

Tepat (Malang: Gandum Mas, 2000). 8
} 
Konseling membuat orang menjadi percaya sehingga orang itu mau berubah dalam tingkah lakunya. Dan sungguh-sungguh mau menerima anugerah Tuhan untuk menjadi penyembah-penyembah di dalam roh dan kebenaran. Deskripsi makna konseling dalam kitab suci terdiri atas: pertama, menjadi ciptaan baru di dalam Kristus. Kedua, Mempunyai Pikiran yang Baru untuk Dunia Baru. Ketiga, Mempunyai Hati yang Baru. Keempat, Menjadi murid Yesus. Konseling membuat orang menjadi tahu akan kesalahan dan mengoreksi diri sehingga menjadi hidup lebih baik dari sebelumnya. Saran dari penelitian ini adalah untuk dikembangkan penelitian ini secara pratika untuk menjawab permasalahan-permasalahan real yang terjadi dalam bidang pelayanan konseling kristen. Pelayanan konseling akan menjadi efisien dan terjawab semua masalah yang terjadi kalangan rumah tangga, remaja yaitu mencari jati diri dan maupun masalah-masalah yang dihadapi setia pribadi. Setiap masalah atau pergumulan mempunyai jawaban yaitu jalan keluar, jawabannya hanya terdapat kepada Kristus.

\section{DAFTAR PUSTAKA}

Beek, Aart Martin van. Stretegi Pelayanan Terpadu-Suatu Pedoman Pastoral. Jakarta: Pelkesi, 1992.

Beek, Aart van. Pendampingan Pastoral. Jakarta: BPK Gunung Mulia, 2007.

Beek, Martin Van. Konseling Pastoral. Semarang: Satya Wacana, 1992.

Brek, Yohan. Ibadah Generasi Milenial: Pendekatan Teologi Pastoral Dalam Generasi Milenial. Depok: Raja Grafindo Persada, 2019.

Brownlee, Malcom. Gotong Royong Dan Berdikari, Dalam Eka Darmaputera (Ed), Konteks Berteologi Di Indonesia. Jakarta: BPK Gunung Mulia, 2004.

Budiono. Kamus Ilmiah Populer Internasional: Materi Politik, Ekonomi, Hukum, Sosial, Budaya, Agama. Surabaya: Alumni, 2005.

Clinebell, Howard. Tipe-Tipe Dasar Pendampingan Dan Konseling Pastoral. Yogyakarta: Kanisius, 2002.

Collins, Carry R. Pengantar Pelayanan Konseling Kriten Yang Efektif. Malang: Seminari Alkitab Asia Tenggara, 2002.

Collins, Gary R. Konseling Kristen Yang Efektif: Pengantar Pelayanan. Malang: Literatur SAAT, 2012.

Gintings, E. P. Gembala \& Konseling Pastoral. Yogyakarta: ANDI Offset, 2002.

Harun, Hadiwijono. Iman Kristen. Jakarta: BPK Gunung Mulia, 2003.

Heitink, Gerben. Teologi Praktis Pastoral Dalam Era Modernitas-Postmodernitas. Jakarta: Kanisius, 1999.

Hunt, June. Pastoral Konseling Alkitabiah 2: Kebenaran Alkitab Menjawab Masalah Anda. Yogyakarta: ANDI Offset, 2015.

Hurlock, Elizabeth B. Psikologi Perkembangan Suatu Pendekatan Sepanjang Rentang Kehidupan. Jakarta: Erlangga, 2009. 
POIMEN: Jurnal Pastoral Konseling Vol. 1, No.2, pp. 1 - 13, Desember 2020

Imam Gunawan. Metode Penelitian Kualitatif, Teori Dan Praktik. Jakarta: Bumi Aksara, 2013.

Krisetya, Mesach. Bela Rasa Yang Dibagirasakan. Jakarta: Duta Ministri, 2015.

L. M., Yusuf. "INTERPRETASI KATA LOGOS DAN THEOS DALAM YOHANES 1:1.” BONAFIDE: Jurnal Teologi dan Pendidikan Kristen 1, no. 1 (June 15, 2020): 23-43. Accessed July 22, 2020.

http://jurnal.sttissiau.ac.id/index.php/jbs/article/view/1.

Lake, Toni. Pergumulan Di Kala Duka. Jakarta: BPK Gunung Mulia, 1992.

M, YUSUF L. "Yesus Sejarah Dan Kristus Iman.” Veritas Lux Mea (Jurnal Teologi dan Pendidikan Kristen) 2, no. 1 (May 7, 2020): 1-19. Accessed July 22, 2020. http://jurnal.sttkn.ac.id/index.php/Veritas/article/view/62.

Nawawi. Metode Penelitian Kualitatif. Jakarta: Gramedia, 2003.

Neufeld, Rupp Anne. Tumbuh Kembang Bersama Anak. Jakarta: BPK Gunung Mulia, 2009.

Oates, Wayne E. Pastoral Caunseling. Philadelphina: The Westminster Press, 1974.

Stuart, Gordon D. Fee \& Douglas. Hermeneutik: Bagaimana Menafsirkan Firman Tuhan Dengan Tepat. Malang: Gandum Mas, 2000.

Susabda B. Yakub. Konseling Pastoral. Jakarta: BPK Gunung Mulia, 2014.

Sutarno. Di Dalam Dunia Tetapi Tidak Dari Dunia. Jakarta: BPK Gunung Mulia, 2004.

Suyadi. Psikologi Belajar Pendidikan Anak Usia Dini. Yogyakarta: Pt. Bintang Pustaka Abadi., 2010.

Tjandrarini, Kristiana. Bimbingan Konseling Keluarga. Salatiga: Widya Sari Press, 2004.

Wirsyaputra, Totok S. Mengapa Berduka Kreatif Mengelola Perasaan Berduka.

Yogyakarta: Kanisius, 2003.

Wiryasaputra, Totok S. Grief Psychotheraphy. Yogyakarta: Pustaka Referensi, 2019.

—. Ready to Care. Yogyakarta: Galang Press, 2006. 